\title{
8
}
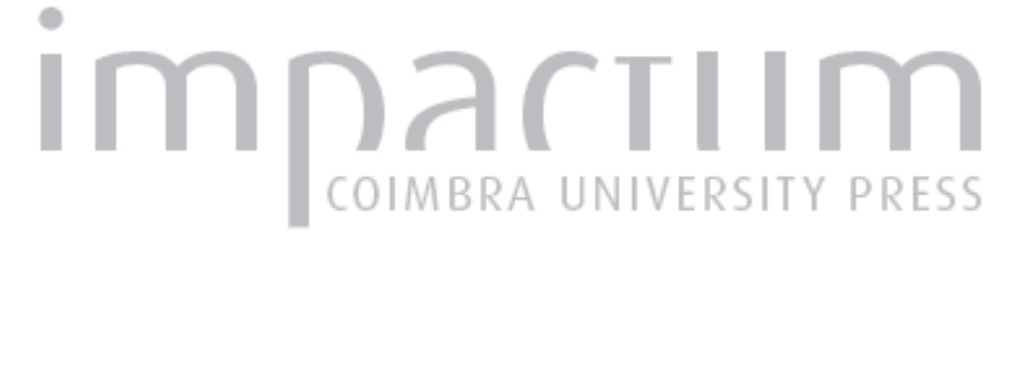

\section{A reorganização do Parque Escolar Nacional e a importância das componentes geográficas na metodologia adotada}

Autor(es): $\quad$ Cordeiro, A. M. Rochette; Santos, Lúcia; Caridade, Paulo

Publicado por: $\begin{aligned} & \text { Faculdade de Letras da Universidade de Coimbra, Departamento de } \\ & \text { Geografia }\end{aligned}$

URL

persistente:

URl:http://hdl.handle.net/10316.2/30265

DOI: $\quad$ DOI:http://dx.doi.org/10.14195/0871-1623_32_27

Accessed : $\quad$ 26-Apr-2023 12:00:00

A navegação consulta e descarregamento dos títulos inseridos nas Bibliotecas Digitais UC Digitalis, UC Pombalina e UC Impactum, pressupõem a aceitação plena e sem reservas dos Termos e Condições de Uso destas Bibliotecas Digitais, disponíveis em https://digitalis.uc.pt/pt-pt/termos.

Conforme exposto nos referidos Termos e Condições de Uso, o descarregamento de títulos de acesso restrito requer uma licença válida de autorização devendo o utilizador aceder ao(s) documento(s) a partir de um endereço de IP da instituição detentora da supramencionada licença.

Ao utilizador é apenas permitido o descarregamento para uso pessoal, pelo que o emprego do(s) título(s) descarregado(s) para outro fim, designadamente comercial, carece de autorização do respetivo autor ou editor da obra.

Na medida em que todas as obras da UC Digitalis se encontram protegidas pelo Código do Direito de Autor e Direitos Conexos e demais legislação aplicável, toda a cópia, parcial ou total, deste documento, nos casos em que é legalmente admitida, deverá conter ou fazer-se acompanhar por este aviso. 


\title{
A Reorganização do Parque Escolar Nacional e a importância das componentes geográficas na metodologia adotada
}

\author{
A. M. Rochette Cordeiro \\ Departamento de Geografia e Centro de Estudos de Geografia e Ordenamento do Território (CEGOT). Faculdade de Letras da Universidade de Coimbra. \\ rochettecordeiro@fl.uc.pt
}

\section{Lúcia Santos}

Bolseira de Investigação. Faculdade de Letras da Universidade de Coimbra. luciarsantos@gmail.com

\section{Paulo Caridade}

Bolseiro de Investigação. Faculdade de Letras da Universidade de Coimbra. pjcaridade@gmail.com

\section{Resumo:}

A rede educativa portuguesa sofreu, no último século, uma significativa e evolução, marcada não só por nuances políticas e ideológicas entretanto observadas, mas também pelas transformações que foram ocorrendo na demografia e na mobilidade, em especial na segunda metade do século XX.

Estas transformações tornaram desajustada a rede educativa deste princípio de século XXI, uma vez que os próprios edifícios escolares, muitos deles herdados do "Plano dos Centenários", não respondem aos desafios educativos que a escola atual exige.

Impôs-se, assim, a reorganização do parque escolar nacional, no sentido de o tornar consentâneo não só com a realidade atual, mas fundamentalmente com as necessidades previstas para as próximas décadas, numa lógica de planeamento estratégico.

Palavras-chave: Territorialização da educação. Reorganização do parque escolar e planeamento estratégico.

\section{Résumé:}

La réorganisation du Parc Scolaire National et l'importance des composants géographiques dans la méthodologie adoptée

Le réseau éducatif portugais a souffert au cours du dernier siècle, une significative et évolution, marquée non seulement par des nuances et des idéologies auparavant observées, mais aussi par les transformations qui ont eu lieu au niveau de la démographie et de la mobilité, surtout dans la seconde moitié du XXe siècle. Ces transformations font en sorte que le réseau éducatif soit désajusté par rapport au XXIe siècle, vu que les propres bâtiments scolaires, provenant pour la plupart d'entre eux de l'héritage du «Plano dos Centenários», ne répondent pas aux défis éducatifs que l'école exige actuellement. La réorganisation du réseau scolaire national s'impose afin de le rendre compatible non seulement avec la réalité actuelle, mais fondamentalement avec les besoins prévus pour les prochaines décennies, dans une logique de planification stratégique.

Mots-clés: Territorialisation de l'éducation. Réorganisation nationale et planification stratégique.

\section{Abstract:}

Education network reorganization and the importance of the geographic components in the methodology adopted

Over the last century, the Portuguese schooling system suffered strong changes that have been marked not only by the political and ideological nuances observed, but also by the changes that occurred in the demographics and mobility, specially in the second half of the twentieth century. 
Nonetheless, these changes made the schools inadequate for the beginning of the 21st century, since the current buildings, the vast majority a legacy of the "Plano dos Centenários", do not respond to the educational challenges of the present moment.

Therefore, it became necessary to make a strategic planning, in order to make the system consistent not only with the current reality, but fundamentally with the expectations for the coming decades. .

Keywords: Territorialization of education. National reorganization and strategic planning.

\section{Algumas notas introdutórias}

A rede educativa portuguesa sofreu, em especial no decorrer do último século, uma grande evolução determinada pelas mudanças políticas e ideológicas, mas também pelas transformações socioeconómicas, observadas em particular após o final da $2^{\text {a }}$ Guerra Mundial.

Nestas últimas seis décadas o território do nosso país mudou profundamente, tendo-se passado de um país profundamente rural, com uma população distribuída pelo todo do território nacional e onde as acessibilidades se apresentavam como profundamente deficitárias, a um país predominantemente urbano, com a população concentrada na sua faixa litoral e com boas acessibilidades em grande parte do território nacional.

Simultaneamente observa-se também uma alteração profunda da estrutura demográfica portuguesa, com a pirâmide etária a oferecer uma imagem de um país desenvolvido, onde a base se tem vindo a estreitar, com uma perda significativa de jovens em idade escolar, e um significativo envelhecimento populacional, que caracteriza estas últimas décadas (Martins et al., 2011; CordeIro e MarTins, in press).

Ao longo deste período, fruto das inúmeras políticas desenvolvidas no sentido de recuperar o atraso educativo para com os restantes países europeus, observaram-se várias reformas das quais resultaram evoluções ao nível dos conteúdos educativos, das práticas pedagógicas e mesmo de novas necessidades em termos dos espaços físicos.

Nesse sentido, e tendo em consideração as transformações demográficas, socioeconómicas e de mobilidade que modificaram as lógicas das distâncias no território nacional, bem como as expetativas criadas em torno de uma tão necessária potenciação da educação em Portugal, sucessivos governos equacionaram a reorganização da rede do parque escolar, se bem que só a partir de 2003, e particularmente de 2006, é que se criaram condições para efetivar tal desígnio (Rodrigues, 2010). Primeiro com a realização de mais de três centenas de Cartas Educativas Municipais e, num segundo momento, com a implementação do projeto "Projeção do Parque Escolar por NUT III a 2013”.

\section{O Enquadramento as Cartas Educativas Municipais no contexto da evolução da rede educativa: do nacional ao local}

Durante décadas (pode mesmo afirmar-se, desde a reforma Pombalina) o Estado foi decidindo as políticas e a organização de todo o sistema educativo nacional, ou seja, desde há muito que tudo é definido em torno do Poder Central e isto sempre numa lógica centralizadora e claramente nacional.

Com a implementação da Lei de Bases do Sistema Educativo (1986), a administração central, ao estabelecer o quadro geral do sistema educativo, consagrava a premência do planeamento, particularmente da rede educativa, o que, numa fase inicial, passava pela ela boração de um documento base, a Carta Escolar. Era, pode afirmar-se, uma tentativa de abertura à descentralização, com uma ténue passagem da lógica nacional à lógica local. No entanto, é a partir de 2003, com a publicação do Decreto-lei n ${ }^{\circ}$ 7/2003 de 15 de Janeiro, que se assiste a uma verdadeira mudança na política educativa (que envolve mesmo o próprio conceito de "escola"), consubstanciada em parte na Carta Educativa, a qual passava a ter um carácter obrigatório.

As premissas que eram enunciadas nas duas propostas (Carta Escolar vs Carta Educativa) denunciavam duas perspetivas muito diferentes em termos de planeamento. Longe ficaram os tempos em que o conceito de "escola" passava pela sua identificação enquanto edifício isolado. As atuais conceções, ao privilegiarem uma perspetiva de escola enquanto parte integrante de uma rede de espaços diferenciados de educação, formação e, mais recentemente, sociais e culturais, cuja integração deve ser assumida numa clara interligação entre a comunidade escolar e as populações, mostram outras preocupações em torno do sistema educativo.

Passou a ser destacada a conceção de "escolaorganização", a qual articula as diversas unidades de educação e formação com os serviços e equipamentos sociais, desportivos e culturais, possibilitando, deste modo, uma programação de equipamentos subordinada a princípios estratégicos que consagram a diversida- 
de, flexibilidade e versatilidade de soluções e a complementaridade na utilização e gestão dos recursos e apoios (FAZENDEIRO, 1992).

Assiste-se, assim, à transição de uma noção de "vida escolar" para uma noção mais complexa e enredada de "vida socioeducativa", que enquadra cada vez mais a escola no seu meio envolvente.

Deve, desde logo, ser referido que, num primeiro momento, e ainda no quadro da Lei de Bases do Sistema Educativo, a Carta Escolar era entendida como uma simples caracterização do sistema educativo, na qual deveria ser efetuado todo o levantamento dos estabelecimentos de ensino de um município, tendo como referência um determinado ano letivo. Era pensada como um diagnóstico inventariativo e não prospetivo, que se assumia como uma "foto instantânea" de um determinado momento e não como um verdadeiro documento de planeamento de um território (MARTINS et al., 2011).

Num segundo momento, no quadro do Decretolei $n^{\circ}$ 7/2003 de 15 de Janeiro, a Carta Educativa passa a ser entendida como um documento dinâmico, cujos conceitos de base, parâmetros e metodologia deveriam ter como objetivo o planeamento do sistema educativo e, particularmente, da rede educativa (MARTINs et al., 2011). Mais que caracterizar e diagnosticar o momento atual, esta prespetivava a necessidade de incluir diferentes projeções com vista à aferição das necessidades educativas futuras, nomeadamente a de assegurar o adequar da rede escolar ao território, para que, em cada momento, as ofertas educativas disponíveis a nível municipal respondam à procura efetiva, sendo que para tal deveria observar o desenvolvimento demográfico e socioeconómico de cada município (MARTINs et al., 2011).

A publicação deste Decreto-lei impõe a obrigatoriedade de realização da Carta Educativa na totalidade dos municípios do nosso país, passando, em teoria, o processo de reorganização da rede, do âmbito nacional à responsabilidade local. As autarquias passavam a ter uma responsabilidade direta na política educativa do seu próprio território municipal.

Ocorre assim uma transformação radical (embora apenas no conceito) da visão que se pretendia para o planeamento na educação.

De uma perspetiva histórica de centralização no Estado da implementação do sistema educativo, passava-se a equacionar a rede escolar numa perspetiva mais local. Esta mudança radical de escala, sem que para tal estivessem muitos dos agentes preparados, embora se traduza numa efetiva transformação de mentalidade de muitas Autarquias quanto ao sistema educativo, mostrou o quão mal preparada foi esta primeira fase de tentativa do que se pode considerar como a "municipalização" da educação.

Durante os últimos anos da primeira década do século XXI, as mais de três centenas de autarquias nacionais desenvolveram esforços para a elaboração da Carta Educativa. O resultado foi a realização de documentos bastante díspares, onde a reorganização da rede educativa foi equacionada, muitas vezes, não numa lógica puramente técnica, mas, acima de tudo, política, pouco consentânea com os seus principais objetivos, tendo sido muito poucos os territórios a trabalhar segundo lógicas intermunicipais em territórios de fronteira (CORDEIRO e MARTINs, in press).

A procura de um salto qualitativo para a educação no nosso país, com a participação ativa do poder local, saiu, assim, em muitos casos, desvirtuada. Quando se analisam as diferentes Cartas Educativas Municipais constata-se, de imediato, que se poderá vir a assistir ao desenvolvimento das novas políticas educativas municipais a diferentes velocidades, uma vez que as propostas de reorganização da rede educativa apresentadas refletem lógicas muito distintas, podendo levar à criação de novas desigualdades no acesso à educação entre territórios municipais vizinhos, ou mesmo, no seio de um mesmo território municipal.

Esta transformação de escala de análise efetuouse sem que preliminarmente se tivesse realizado um trabalho a escala intermédia de avaliação das diferentes formas possíveis de concretizar esta mudança de paradigma, razão pela qual se encontram forçosamente trabalhos de qualidade muito díspar.

\section{A reorganização da rede escolar à NUT III de 2008: do local à sub-região (e ao nacional).}

Neste contexto, e como esse trabalho de análise à escala intermunicipal não foi na altura equacionado, urgia então realizar um estudo que não só viesse a agregar a totalidade das propostas municipais entretanto realizadas para o território nacional, mas, em especial, que viesse avaliar a validade das mesmas, funcionando assim como uma grelha de análise coerente em termos regionais e mesmo nacionais (a tão necessária monitorização). Impunha-se deste modo a implementação de um amplo projeto de reorganização do parque escolar, agora também introduzindo uma perspetiva supramunicipal, no sentido de o tornar consentâneo não só com a realidade atual, mas fundamentalmente com as que se perspetivam para as próximas décadas no nosso país. 
Foi neste contexto que foi equacionado pelo Gabinete de Estatística e Planeamento da Educação do Ministério da Educação (GEPE) o estudo "Projeção do Parque Escolar por NUT III a 2013", que apresentava como objetivo primeiro tornar as propostas da rede escolar nacional numa lógica de espaço territorialmente coeso e adequadamente distribuído e dimensionado, respondendo, com elevados níveis de eficácia e eficiência, às carências e problemas existentes ou previstos, mas tendo sempre uma base local. Com o objetivo de validar e uniformizar o trabalho desenvolvido a nível local passou-se, novamente, a uma escala de análise nacional, embora agora recorrendo como unidade administrativa de suporte, às sub-regiões (NUT's III), enquanto unidades territoriais tendencialmente homogéneas e cujos territórios municipais que as integram apresentam fortes relações entre si (CORDEIRo, 2011).

Através da reorganização do parque escolar nacional pretendia-se que este, então constituído por cerca de 10000 estabelecimentos de ensino (CoRdeIRO e MARTINS, in press), sofresse uma significativa redução, no sentido de adequar as condições físicas, espaciais e materiais às exigências pedagógicas, administrativas e sociais que tinham vindo a ser caucionadas pela ampla reforma avançada pelo Ministério da Educação, e que derivam, em muito, das transformações observadas em Portugal no último meio século, quer em termos populacionais, quer da rede viária e das mobilidades (MARTINS et al., 2011; CORDEIRO, 2011). Estas encontravam-se estruturadas nos primeiros níveis, entre outras, nas lógicas associadas aos "Centros Escolares" e à "Escola a Tempo Inteiro", já que a transformação da demografia escolar entretanto observada teve o seu principal reflexo no $1^{\circ} \mathrm{CEB}$.

$\mathrm{Na}$ visão desta "reforma" a nova tipologia de equipamentos educativos proposta - Centro Escolar deveria caracterizar-se pela qualidade funcional, com a integração de pelo menos dois níveis de ensino, e por apresentarem um conjunto de espaços - refeitório / polivalente, biblioteca, espaços para as diferentes atividades de enriquecimento curricular e equipamento desportivo - que deveriam contribuir para a melhoria da qualidade do espaço educativo, devendo ser defendido que estes espaços, e numa lógica de otimização em termos de planeamento, fossem preferencialmente partilhados pelas comunidades locais.

Esta perspetiva de espaço educativo permitia, por um lado, a consolidação do objetivo estratégico de garantir a "Escola a Tempo Inteiro", e, por outro lado, a diminuição da dispersão de recursos financeiros, materiais e humanos, pelo que a sua construção passou a ser uma das prioridades do Quadro de Referência Estratégico Nacional (QREN).

\subsection{A reorganização do parque escolar em termos nacionais: as razões motivadoras.}

A evolução que a rede educativa portuguesa sofreu ao longo do último século foi o resultado não só da evolução dos conceitos e objetivos que o Estado português ia pretendendo para o sistema educativo (CORDElRo e MARTINS, in press; AlCOFORADo et al., in press), mas também das grandes transformações que foram observadas em termos da demografia, da socioeconomia, da mobilidade e, em especial, dos objetivos em termos de desenvolvimento da sociedade portuguesa durante todo este período e, em particular, na $2^{\text {a }}$ metade do século passado (CoRdeIRo, coord., 2008; MARTINs et al., 2011).

Assim, no início da década de 50, o facto de Portugal apresentar uma pirâmide etária jovem (Figura 1a), reflexo de um país que se assumia como em vias de desenvolvimento, no qual se observava uma economia essencialmente baseada na agricultura e uma rede de acessibilidades profundamente deficitária, factos que se tinham obrigatoriamente de refletir na distribuição dos estabelecimentos de ensino. Foi no $1^{\circ} \mathrm{CEB}$ (o ensino primário) que se observou a nível nacional a definição da rede educativa do final da primeira metade do século XX - o "Plano dos Centenários" (CoRdeIRo coord., 2008; MARTINs et al., 2011).

O elevado número de crianças que se observava nesse momento nos diferentes setores do território nacional, bem como a notória dificuldade de deslocação que resultava de uma deficiente rede viária, constatável mesmo entre os diferentes lugares de uma mesma freguesia, contribuiu decisivamente, em particular no início do $3^{\circ}$ quartel do século passado, para uma significativa expansão do número de "escolas primárias", estabelecimentos de ensino que na sua esmagadora maioria apresentavam apenas uma ou duas salas de aula.

Em situação perfeitamente oposta, o nosso país apresenta, neste início do século XXI, uma pirâmide etária envelhecida (Figura 1a), uma economia maioritariamente baseada nos serviços e uma rede de acessibilidades que transformou por completo a relação distância-tempo em vastos setores do território nacional, encurtando distâncias, tornando locais anteriormente longínquos, hoje bastante mais próximos. A agravar esta transformação brutal, observa-se uma "litoralização" da concentração da demografia portuguesa (Figura 1b), o que, associado ao êxodo migratório das décadas de $60 / 70$ do século passado, transformou amplos sectores 
do interior de Portugal, num território envelhecido e despovoado (Figura 1c).

Parece ser inquestionável que a década de 70 assume-se como ponto de viragem (muito por força da emigração observada na década anterior), marcando, desse modo, o início desta evolução demográfica, a qual, tal como foi referido, se refletiu de imediato numa súbita diminuição do número de estabelecimentos do $1^{\circ}$ CEB em funcionamento, bem como, a partir de 1975, num decréscimo da população escolar que frequentava este nível de ensino (CORDEIRo e MARTINS, in press). Este decréscimo (que continua ainda nos nossos dias) ocorria em contraciclo com o que se observava nos restantes níveis de ensino, os quais viam aumentar o número de estabelecimentos e de alunos matriculados, manifestamente como resultado de uma modificação não só associada à democratização do ensino, mas também das próprias mentalidades (CoRdEIRO e MARTINS, in press).

A crescente diminuição das classes etárias mais jovens e o aumento dos escalões etários dos mais idosos contribui para o agravar da situação. Assim, a população escolar tem vindo a registar um decréscimo contínuo, que mais recentemente se estendeu também a outros níveis de ensino, apesar de este ser mais evidente no $1^{\circ}$ CEB. Esta foi a razão pela qual o projeto, numa primeira análise, se debruçava sobre a necessidade de um sucessivo encerramento de estabelecimentos de ensino, em especial nos sectores de baixa densidade do território nacional.

A par destas transformações observou-se também uma alteração dos padrões sociais, sem precedentes no caso português. Para estas contribuíram de forma decisiva não só as modificações económicas associadas à criação e crescimento de uma importante classe média, mas também a integração da mulher no mercado de trabalho e o fenómeno de terciarização da sociedade.

De igual modo, a alteração dos padrões de mobilidade entretanto verificada (em especial nas últimas décadas do século $X X$ ), reflete-se também numa transformação dos fluxos laborais, em geral, e dos fluxos escolares, em particular, facto que no caso educativo contribuiu para uma alteração drástica das áreas de influência e dos fluxos associados a cada estabelecimento de ensino. Às questões da melhoria da mobilidade associa-se o facto de a maioria dos pais e encarregados de educação terem vindo a apresentar uma crescente tendência na opção por matricular os seus educandos nos estabelecimentos de ensino mais próximos do seu local de trabalho, e não, próximos da sua residência, como se verificava no momento em que as mães e os avós se encontravam muito presentes no dia-a-dia dos núcleos familiares, reforçando assim as alterações dos fluxos.

Acresce ainda referir que ao longo destas décadas se observou uma significativa evolução ao nível das práticas pedagógicas, quer do ponto de vista dos conteúdos educativos, quer do ponto de vista das necessidades em termos de espaço físico.

Deste modo, e tendo em consideração as significativas transformações do Portugal das últimas décadas - a evolução demográfica e socioeconómica, a alteração dos padrões de mobilidade e a transformação das práticas pedagógicas - parece ser inquestionável que a rede escolar deste princípio de século XXI se tornava claramente desajustada com a realidade educativa. Também os edifícios, muitos deles ainda herdados do "Plano dos Centenários", não respondiam (mesmo considerando as
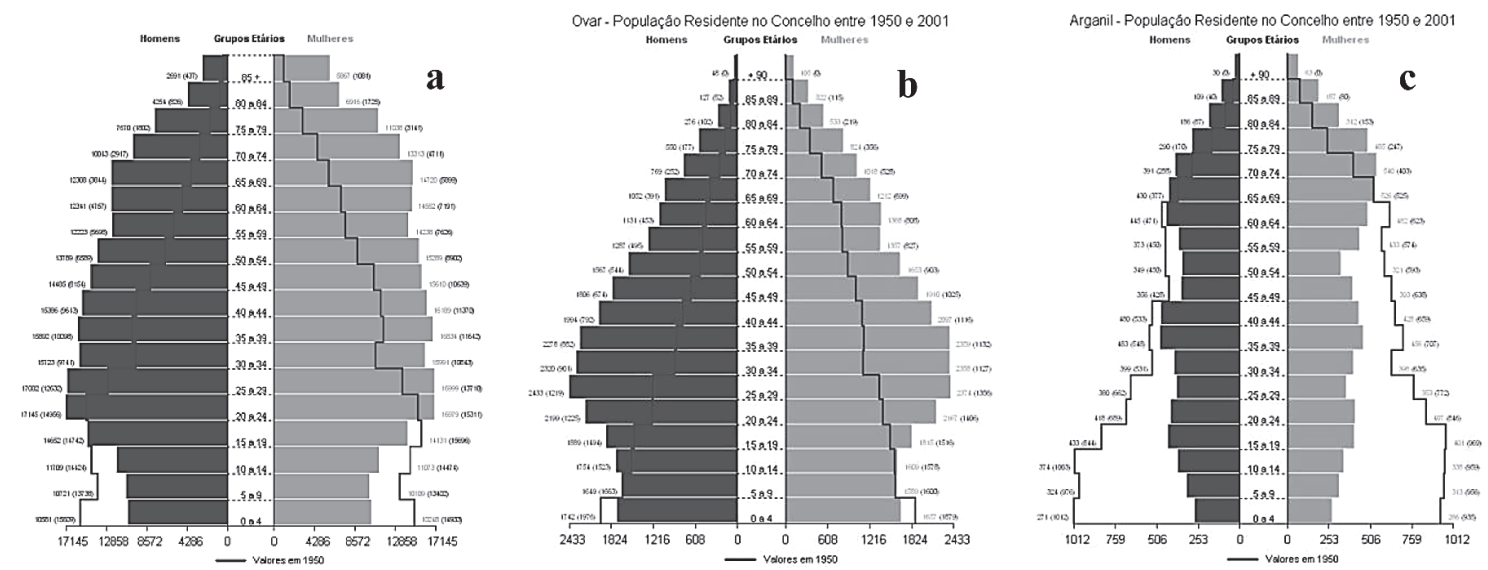

Figura 1

Evolução demográfica em Portugal, de 1950 a 2001: em Portugal (a), no Município de Ovar (b) e no Município de Arganil (c). 
transformações observadas com a reforma de Veiga Simão) aos desafios educativos do momento presente.

Porém, esta evolução não ocorre de modo homogéneo no todo do território nacional. No início do século XXI são ainda mais evidentes as dicotomias existentes, sendo notórios os contrastes norte/sul e litoral/interior que se têm agravado nas últimas décadas, devendo porém ser referido que é, de uma forma significativa, a dicotomia urbano/rural aquela que se tem vindo a agudizar. Ao Portugal urbano organizado em rede, caracterizado pelo aparecimento do arquipélago urbano constituído pelas grandes regiões metropolitanas de Lisboa e Porto, do cordão urbano do litoral algarvio e ainda de várias aglomerações urbanas de média e até, nalguns casos, pequena dimensão, opõem-se amplos sectores do território que sofrem um processo de isolamento, desertificação e envelhecimento crescente.

No entanto, esta visão dicotómica do território nacional, que sublinha a oposição entre o país do litoral desenvolvido e de alta densidade e o país subdesenvolvido do interior de baixa densidade, deve ser evitada, uma vez que a realidade é bastante mais complexa, como o demonstram as dinâmicas de evolução observadas nas últimas décadas. Em termos genéricos pode mesmo observar-se que a "interioridade", enquanto processo socioeconómico, estende-se até ao litoral em diversas áreas do país, assim como os sectores em desenvolvimento emergem em alguns (poucos) territórios do interior.

Por tudo isto, tornava-se por demais evidente que uma reorganização do parque escolar à escala nacional não poderia obedecer às mesmas linhas estratégicas na totalidade do território nacional, já que a delimitação dos novos Territórios Educativos, em circunstância alguma, não podia ignorar as diferentes dinâmicas e características observadas no nosso país, obrigando à sua adaptação, servindo, como peças fundamentais de análise, as Cartas Educativas Municipais entretanto realizadas, aprovadas e homologadas (Cordeiro, 2011).

\section{As metodologias definidas e utilizadas no projeto de reorganização da rede escolar}

Naturalmente que um projeto com as caraterísticas que este apresenta tem de obedecer a uma metodologia rigorosa, mas que deve ser obrigatoriamente associada a um conjunto de variáveis muito diversificadas. Neste domínio, foram consideradas as componentes geográficas associadas aos territórios, as quais vieram a assumir uma importância decisiva.
Parece ser inquestionável que até aos anos 70 o tipo de planeamento em uso na educação (aliás como em muitas outras áreas - saúde, território e economia) se centrava essencialmente na elaboração de planos. Esse instrumento de planeamento tradicional, dada a sua natureza, não conjeturava possibilidade de flexibilidade e de adaptação durante o processo de implementação (Gabinete de Estudos e Planeamento, 1992a; 1992b). Assim, na sua abordagem clássica, o planeamento tradicional baseava-se essencialmente na seleção de métodos e técnicas que permitiam alcançar os resultados desejáveis (utiliza instrumentos prescritivos, inflexíveis, não moldáveis à realidade e incapazes de lidar com a mudança), não valorizando o contexto em que ocorriam as ações. Por essa via, as dinâmicas territoriais eram desvalorizadas, bem como o fator "incerteza" (Santos, 1994; Afonso, 1997).

Assiste-se assim, a partir da década de 70, à emergência de um novo paradigma, o do planeamento estratégico (VASCONCELos e SÁ, 1990), o qual procura compaginar-se, através de uma visão multidimensional (holística) e integrada, com o paradigma da complexidade e da pós-modernidade (SANTOS, 1994). Conceptualmente, o planeamento estratégico promove uma visão para o território fundamentada num diagnóstico prospetivo e numa gestão de longo prazo (CORDEIRo e MARTINS, in press).

Este tipo de planeamento caracteriza-se pelo carácter multidisciplinar e participado, pela clara definição das funções e responsabilidades de cada nível de intervenção, por um bom suporte de informação, por uma articulação entre a gestão e o planeamento e ainda por uma visão estratégica e flexibilidade (CABRAL e MARques, 1996). Com o aparecimento do planeamento estratégico, novos conceitos e instrumentos começam a emergir, onde as abordagens estratégicas territoriais assumem uma nova lógica, observando-se que o processo de planeamento se começa a sobrepor ao plano, ganhando os instrumentos de execução maior peso. A monitorização e a avaliação passam a ser peças fundamentais. Estes novos conceitos e instrumentos foram inspiradores para algumas das mudanças que viriam a ocorrer, entre outras, no campo educativo, e aqui, em particular, no domínio do planeamento da rede escolar, mas que em termos nacionais pouco foram assumidos.

Deste modo, no início da década de 90 é a própria administração educativa (Gabinete de Estudos e Planeamento, 1992a; 1992b) que, face aos problemas e carências com que se debatia a rede escolar ao nível das "regiões" e dos municípios (CoRdeIRo, 2011), passa 
a assumir a indispensabilidade de um planeamento da rede escolar de características estratégicas (FAZENDEIRO, 1992).

É com base nestes pressupostos de planeamento estratégico que todo o projeto "Projeção do Parque Escolar por NUT III a 2013" foi equacionado nas enumeras reuniões tidas entre as equipas técnicas do Gabinete de Estatística e Planeamento da Educação do Ministério da Educação e da Faculdade de Letras da Universidade de Coimbra. A concretização do projeto de reorganização do parque escolar obrigou assim, logo num primeiro momento, à assunção de um conjunto de conceitos de base, parâmetros e metodologias, de forma a definir a estrutura do projeto. Para a realização deste projeto sentiu-se a necessidade de integrar um vasto conjunto de indicadores físicos e humanos, como são as condicionantes naturais, a rede de acessibilidades e a dinâmica demográfica (passada, presente e futura) de cada um dos territórios em análise.

Assim, e se, por um lado, se apresentava como fator determinante o conhecimento das atuais dinâmicas da população e do próprio povoamento, por outro lado, o prospetivar em termos futuros, nomeadamente da demografia, apresentou-se como essencial, uma vez que o entendimento foi sempre no sentido de realizar um processo de planeamento estratégico. 0 planeamento de equipamentos coletivos não pode contudo esquecer as condicionantes físicas, quer quanto à sua localização, quer o seu peso na mobilidade da população - escolar e laboral.

A análise das condicionantes naturais (como a morfologia ou os cursos de água de maior dimensão) assume um papel determinante, uma vez que estas condicionantes se apresentam como responsáveis por algumas fronteiras e alguns constrangimentos que se observam no território nacional em termos da rede viária, e que são responsáveis pela criação de alguns dos estrangulamentos observados em termos de mobilidade em diferentes setores do território nacional.

Acresce o facto da intensa transformação de que a rede viária foi alvo nas últimas três décadas ter introduzido importantes alterações nos padrões de mobilidade da população, intensificando a distinção existente entre os estabelecimentos de ensino localizados em áreas rurais, periurbanas e urbanas e respetivos fluxos associados.

Relativamente às dinâmicas demográficas importava efetuar não só a avaliação dos quantitativos e da estrutura da população no momento atual (observando também as tendências das últimas décadas), mas, sobretudo, determinar os seus quantitativos e as suas características futuras, isto com o claro objetivo de definir os cenários para os diferentes territórios. Porém, a leitura das alterações demográficas registadas nas últimas décadas foi também integrada no contexto alargado da evolução dos respetivos sistemas sociais, culturais, económicos e políticos dos diferentes territórios, uma vez que a situação atual de uma comunidade poderá revelar muito sobre qual poderá vir a ser o seu futuro.

O conhecimento da dinâmica demográfica revelase assim como uma das peças fulcrais para que viesse a ser possível, com a antecedência e a ponderação necessária, refletir sobre as principais tendências que se prefiguram neste início de século, de modo a ordenar o espaço da forma mais adequada e no quadro de uma racionalidade que se pretende dinâmica. Pretendeu-se assim efetuar uma gestão mais eficaz dos recursos que, como bens escassos que são, exigem alguma ponderação nas decisões a tomar, já que os custos associados a um mau planeamento e a uma má gestão terão efeitos duradouros e crescentemente elevados, aliás como pode ser observado no momento presente em muitos dos sectores do território nacional.

O projeto teve assim como base estruturante uma caracterização demográfica que apresentava, inicialmente, a análise de alguns elementos relativos à distribuição, evolução e características da população, dos quais se destacavam os comportamentos evolutivos das décadas mais recentes. Simultaneamente, consideraram-se também as alterações registadas nas freguesias com maior "peso" demográfico de cada município.

Porém, e tendo em atenção o objetivo primeiro do projeto, analisaram-se, num segundo momento, os elementos prospetivos da dinâmica da população.

Em termos metodológicos, o projeto valorizou, do modo particular, o comportamento espacial das variáveis demográficas. Neste particular analisaram-se, não só a população residente, nascimentos, óbitos e saldo migratório, mas também de forma comparativa, índices e tendências evolutivas que traduzem as alterações registadas nos padrões de comportamento da população portuguesa no quadro das mudanças sociais, culturais, económicas e políticas ocorridas em Portugal na segunda metade do século $X X^{1}$.

1 Importa referir que os valores de população residente, excetuando os valores de 1991 e 2001, provenientes dos recenseamentos populacionais, foram retirados das estimativas definitivas de população residente intercensitárias 1991-2000, por um lado, e das estimativas provisórias de população residente 2001-2010, por outro lado, sendo, por esse motivo, os valores a partir de 2001 de carácter provisório. 
O conhecimento das tendências evolutivas apresentou-se como fundamental, mesmo que isso possa significar vir a cometer erros, que serão sempre de menor amplitude tendo em atenção as opções a realizar no quadro das políticas a seguir e dos investimentos que as materializam. As premissas de base foram em todo o caso bastante cautelosas, razão pela qual a evolução poderá maioritariamente superar os valores projetados, tal como constatado com os valores provisórios dos Censos 20112. No sentido de antever os cenários futuros, utilizou-se o método das componentes por coortes como metodologia de base para uma análise mais detalhada (por grupos de idades). Os resultados da aplicação deste método a populações particulares vieram a fornecer informações sobre o volume e a composição (segundo o sexo e as idades) da população em momentos futuros, não tendo em atenção acontecimentos de natureza excecional (catástrofes, guerras, epidemias, entre outras). Os resultados projetados traduzem não só a composição (sexo e idades) da população no presente, como têm que ser interpretados a partir das hipóteses assumidas sobre a evolução, ao longo do período prospetivo, dos comportamentos demográficos - mortalidade, fecundidade e movimentos migratórios.

O momento de partida utilizado foi a data do recenseamento de 2001 (12 de Março de 2001), projetando-se sucessivamente para períodos anuais (município) e quinquenais (freguesia) até 2021.

Os problemas relacionados com a escala geográfica de análise e com a qualidade dos dados foram aspetos que mereceram uma especial atenção no cálculo e interpretação dos resultados da projeção. Em relação ao primeiro aspeto, privilegiou-se a desagregação por município como a escala principal, apresentando também resultados para o nível da freguesia ${ }^{3}$.

Como último elemento, importa sublinhar que os resultados da evolução da população traduzem apenas a consideração das variáveis responsáveis pela dinâmica natural das populações (mortalidade e fecundidade), já que se tornou extremamente difícil obter dados sobre as migrações desagregados,

${ }^{2}$ Foram aferidos os valores projetados para 2011 com os dados provisórios do último Censos. Na realidade, para um grande número dos municípios, o erro foi inferior a $2 \%$, observando-se apenas variações superiores em municípios (ou sectores de municípios) em que se verificou um crescimento urbano significativo na última década.

${ }^{3}$ Importa referir que o cálculo dos valores relativos referentes a cada unidade espacial (freguesia ou município) tem por base os valores absolutos e considera sempre os valores decimais, embora estes estejam nos relatórios propositadamente ocultos, razão pela qual muitas vezes se registam ligeiras diferenças nos resultados apresentados nos quadros. por sexo e idades, para os níveis espaciais utilizados (município e freguesia). Porém, considera-se também a análise dos resultados da componente migratória, tendo em atenção a equação da concordância e a repartição do saldo migratório a partir da estrutura por idade e sexo existente em 2001. Para os anos futuros, considerou-se o saldo migratório correspondente ao último período intercensitário e a estrutura etária projetada. De qualquer forma, as consequências sobre estas variáveis demográficas terão uma tradução pouco expressiva no quadro da evolução projetada.

Foi com base nestes pressupostos e sublinhando que a população no tempo de partida reflete desde logo os efeitos da dinâmica migratória que, para o período 2001-2021, se projetaram os valores de população por sexo e idades. Estes valores devem ser entendidos como tendências, isto no momento do equacionar e planear equipamentos e infraestruturas (e logo de tomar decisões), mas ainda assim, quando comparados com os resultados preliminares do recenseamento de 2011, eles não registam grandes variações.

Feita a análise deste vasto conjunto de fatores de ordem natural e humana, que funcionaram como ponto de partida de todo o projeto, todo o trabalho passou a centrar-se na observação de um segundo, mas ainda mais importante, conjunto de variáveis, este mais diretamente relacionado com o sistema educativo dos diferentes territórios. Neste, em particular, foi de extrema importância a caracterização da oferta e da procura educativa, a análise dos nascimentos registados em cada território em análise, a identificação da área de influência de cada estabelecimento de ensino, bem como a observação dos fluxos associados a cada equipamento educativo (Figura 2) e o estudo da distância-tempo dos percursos dos alunos casa-escola (Figura 3). A todos estes fatores foi associada a realização de projeções da população escolar para os próximos anos.

A identificação da área de influência de cada estabelecimento de ensino e a observação dos fluxos associados a cada equipamento educativo permitiu conhecer a mobilidade dos alunos num determinado território, o que, associado ao estudo da distância-tempo dos percursos dos alunos casa-escola, se tornou uma das ferramentas determinantes no processo de planeamento da nova rede escolar.

Peça fulcral no projeto, foi a realização das projeções da população escolar para os próximos anos letivos (ao município e à freguesia), dados que permitiram equacionar as necessidades em termos de equipa- 
mentos, bem como a sua possível localização, isto em função do número médio de alunos previsto. Para a sua realização tornou-se necessário a observação dos nascimentos no período correspondente e da mobilidade

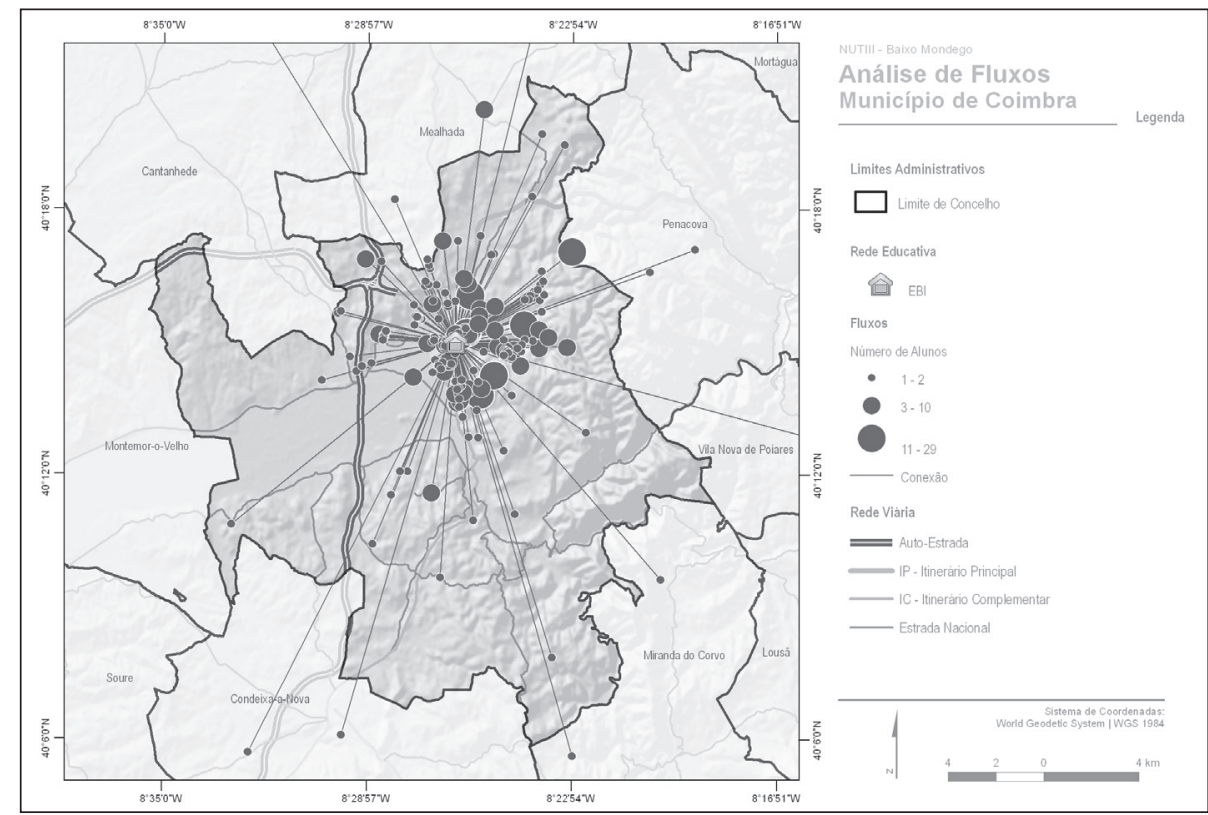

Figura 2

Fluxos da EBI Rainha Santa Isabel (Município de Coimbra).

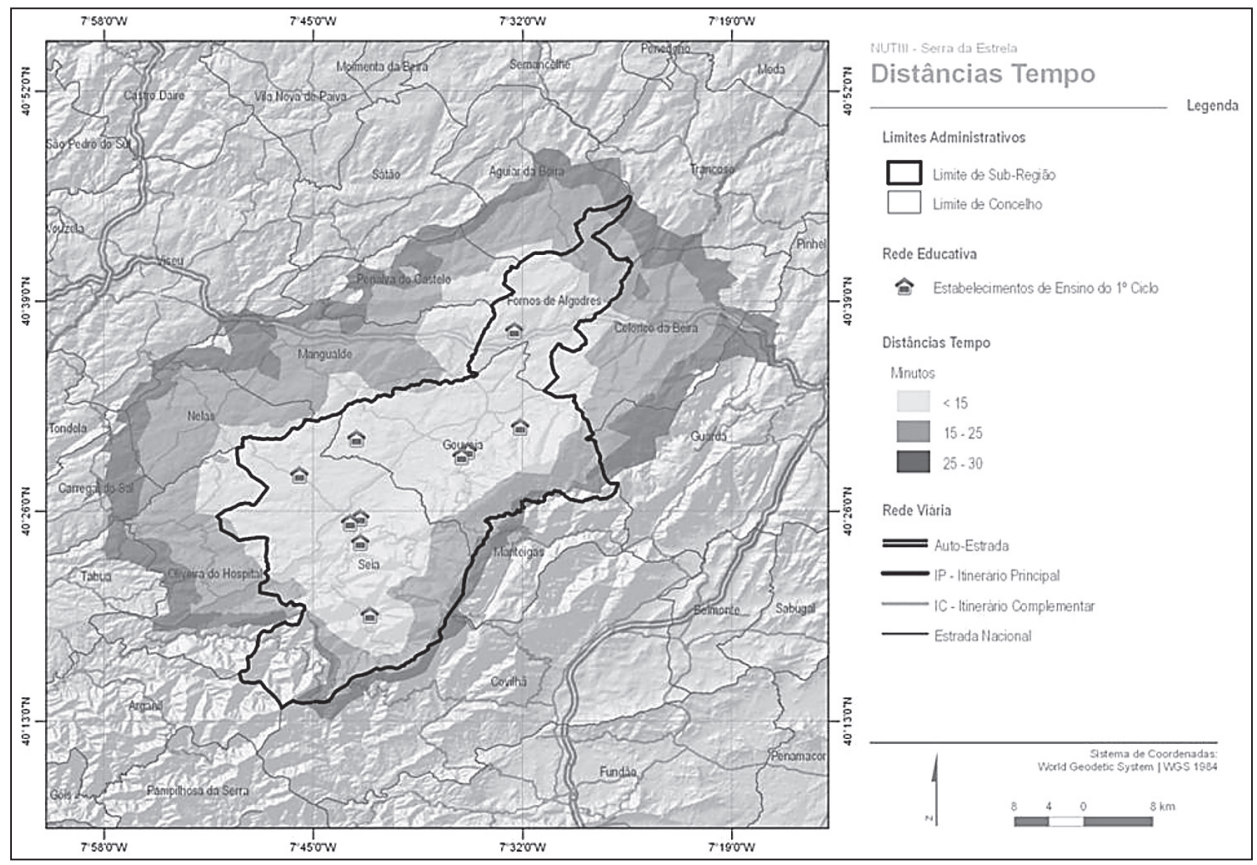

Figura 3

Distância tempo na Sub-região da Serra da Estrela. 
registada, que integra a área de influência e os fluxos associados a cada estabelecimento de ensino ${ }^{4}$.

Simultaneamente, tornou-se necessária uma análise atenta da rede de transportes escolares, uma vez que é inquestionável que uma das principais consequências deste processo de reorganização do parque escolar nacional vai ser o de aumentar a distância entre a residência e o estabelecimento de ensino para muitos alunos, em particular os residentes em setores de baixa densidade. Tal traduz-se, naturalmente, num aumento dos tempos de percurso, num maior número de crianças em movimento, facto que, caso a rede escolar não seja convenientemente planeada, poderá afetar, e de forma decisiva, não só o bem-estar da população escolar, mas também o aumento de custos em transportes escolares das próprias autarquias.

Como facilmente pode ser observado, a consideração de um tão grande número de variáveis tornou o processo de Reorganização do Parque Escolar a uma escala da NUT III, extremamente complexo. Contudo, esta complexidade permitiu que este fosse realmente ao encontro do seu objetivo primeiro, o de adequar a rede educativa ao momento presente e, acima de tudo, perspetivar o seu futuro em territórios tão díspares como aqueles que caracterizam o Portugal deste início do século $X X I$.

No entanto, a plena concretização deste objetivo só se tornaria possível com a possibilidade do equacionar do ultrapassar da fronteira das barreiras administrativas, as quais em muitos sectores são pouco compatíveis com a prática do ordenamento e planeamento do território, uma vez que aquelas podem não ser coincidentes com as fronteiras naturais, pelo que apenas existirá uma verdadeira gestão sustentável quando a análise do território passar a ser efetuada a outra escala - a intermunicipal.

Associado a todo este conjunto de fatores de índole geográfica que a equipa técnica assumiu desde o início do processo de arquitetura do projeto, vieram a integrar-se todo um conjunto de premissas políticas que foram discutidas pelas equipas do Gabinete de Estatística e Planeamento da Educação do Ministério da Educação e da Faculdade de Letras da Universidade de Coimbra.

Neste contexto deve ser referida a tendência crescente de integração nos diferentes equipamentos de mais que um nível de ensino, a necessidade de criar

${ }^{4}$ Esta metodologia foi assumida conscientemente, quer internamente, quer nas inúmeras reuniões realizadas com a Tutela, uma vez que as utilizações de metodologias de índole matemática, que por norma são utilizadas, mostraram-se ainda mais discutíveis quando implementadas a uma escala local. condições para a implementação da "Escola a Tempo Inteiro", aqui com a introdução dos espaços anteriormente referidos para as atividades de enriquecimento curricular, a possibilidade do $1^{\circ} \mathrm{CEB}$ vir a assumir a obrigatoriedade de "uma sala, um ano, um docente", assim como a criação de um cenário diferenciado para a rede escolar, isto em função da perspetiva da obrigatoriedade de 12 anos de escolaridade.

\section{A reorganização do parque escolar nacional: alguns exemplos}

Como facilmente se pode constatar, num país com a diversidade que Portugal apresenta a todos os níveis, parece ser inquestionável que a variedade de soluções necessárias poderia colocar algumas considerações sobre a validade da metodologia apresentada. Porém, o trabalho anteriormente desenvolvido, com a elaboração de cerca de duas dezenas de Cartas Educativas Municipais, bem como a realização da Carta Escolar da Região Autónoma dos Açores (realçando-se nestes projetos, o conhecimento real que o trabalho de campo efetuado ofereceu) permitiu aferir a validade da metodologia, a qual se absteve, logo à parti$\mathrm{da}$, de seguir uma lógica de reorganização a "régua e esquadro", algo que criaria necessariamente grandes desigualdades entre territórios municipais com caraterísticas muito diferenciadas.

Para uma melhor compreensão da aplicação da metodologia optou-se no presente paper por analisar, ainda que de forma sucinta, três municípios que à partida apresentavam condições de base muito diferenciadas. Um município onde a metodologia assentou de modo perfeito ao pretendido pela Tutela - Montemor-o-Velho (CMMV, 2006) - e outros dois onde as diferentes condicionantes colocavam grandes entraves à concretização de todo o processo - Seia e Coimbra (CMS, 2007; CMC, 2008) - e cujas cartas educativas municipais homologadas não refletiam o proposto pela Tutela.

No caso particular do Município de Montemor-oVelho, este, que se assume como o quarto território municipal mais populoso da Sub-região do Baixo Mondego e que se encontra numa posição intermédia com os municípios de Coimbra e Figueira da Foz, em termos demográficos apresentou um decréscimo contínuo de população residente até ao Censos de 2001.

Aos dois sectores que se desenvolvem respetivamente nas Gândaras (sector Norte e Noroeste) e na margem esquerda (sector Sudoeste), que apresentam 
uma forte perda de população, tanto em termos absolutos, como em termos escolares, assim como um acentuado índice de envelhecimento, opõem-se os sectores Central (eixo Montemor-o-Velho/Carapinheira e Meãs do Campo) e Sudeste da margem esquerda do Mondego (freguesias de Pereira e de Santo Varão), onde se tem verificado nos últimos anos um significativo crescimento urbano, em particular no último intercensitário (2001/2011).

Como principal condicionante físico, o território apresenta o rio Mondego (aqui entendido globalmente com a sua extensa planície aluvial), o qual funcionou ao longo dos tempos como um elemento estruturante do território municipal, criando um "efeito barreira" entre as freguesias da margem esquerda e da margem direita (onde se encontra a sede de município), o que se tem repercutido em dinâmicas populacionais e económicas bem distintas.

Esta realidade demográfica e socioeconómica, bem como as características físicas do território, refletiram-se, naturalmente, nas propostas de reorganização do parque escolar. Assim, a proposta de reorganização do parque escolar do Município de Montemor-o-Velho apresentada (e que refletia basicamente o definido pela Tutela), passou pela integração da Educação Préescolar nos estabelecimentos de ensino do $1^{\circ}$ CEB, pela manutenção do $2^{\circ}$ e $3^{\circ} \mathrm{CEB}$ num só equipamento educativo, enquanto o estabelecimento de Ensino Secundário, muito por força dos quantitativos escolares, continuaria a funcionar num único estabelecimento de ensino. Contudo, e muito por força da proximidade dos equipamentos existentes e projetados para a sede do município, "este funcionará como pólo educativo central" (CoRdeIRo coord., 2008). ${ }^{5}$

Atendendo às questões biofísicas e demográficas do município, assim como às perspetivas de evolução urbanística de alguns sectores do território municipal (a proximidade à cidade-região de Coimbra assim o exige), a proposta de reorganização do parque escolar do Município de Montemor-o-Velho assentou na criação de quatro territórios educativos - Arazede, Carapinheira, Montemor-o-Velho e Pereira - (Figura 4), cada um com uma área de influência perfeitamente definida em torno das sedes de Agrupamento de Escolas.

A proposta de reorganização assumiu assim a centralização do $1^{\circ}$ CEB e o Pré-escolar em quatro Centros Escolares, posicionados de forma central nas áreas de planeamento pré-definidas. Com exceção do

${ }^{5}$ De uma forma global, esta foi a solução encontrada para parte dos territórios de baixa densidade onde os pólos funcionam como estruturas verticais e onde a organização da rede reflete, desde logo, as perdas expetáveis de população escolar na próxima década.

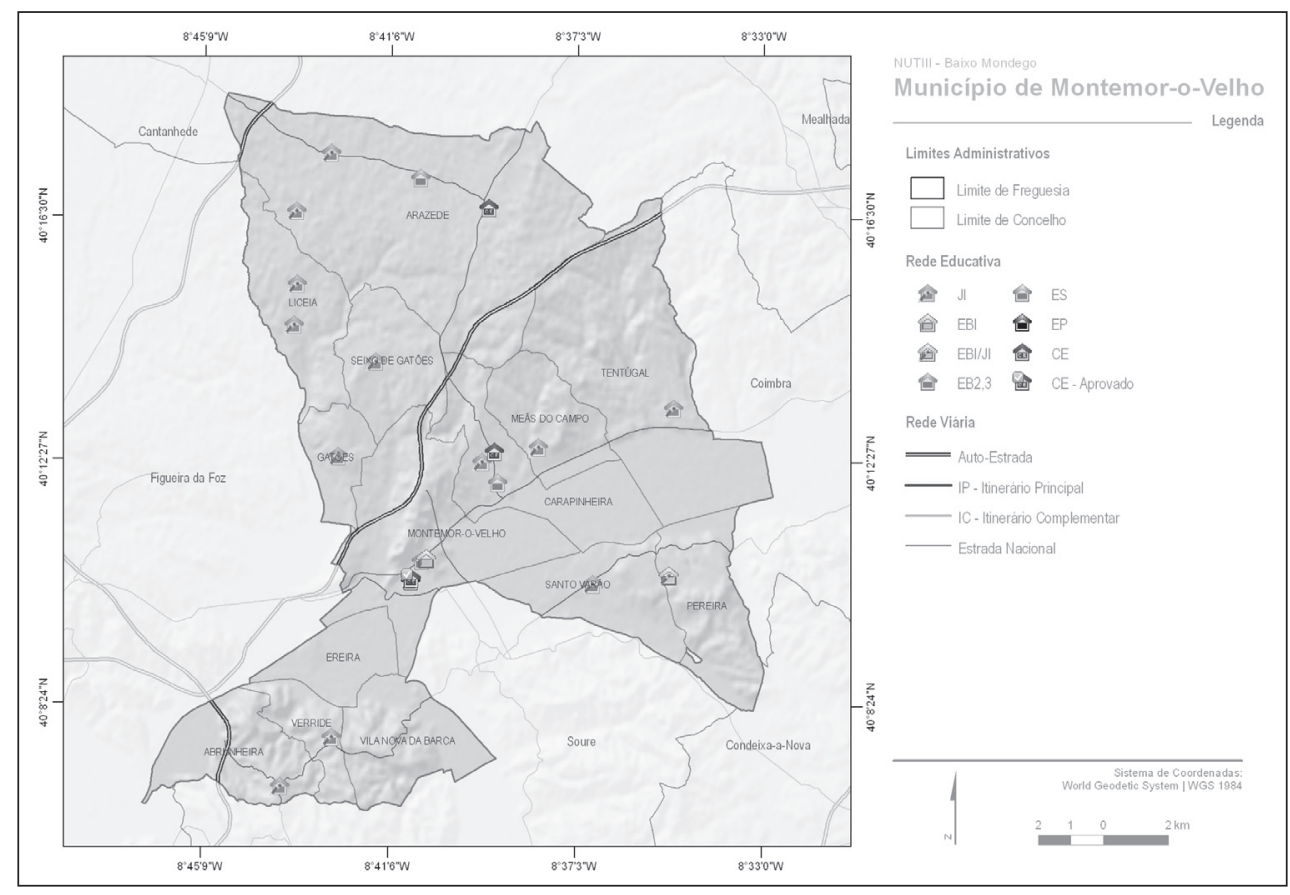

Figura 4

Proposta de reorganização do Município de Montemor-o-Velho (CordeIRo, coord, 2008). 
Território Educativo de Pereira, em que a opção passou pela manutenção da EBI/JI já em funcionamento, foi proposta em cada território educativo a construção de um centro escolar $(\mathrm{EB} 1 / \mathrm{JI})$, os quais deveriam receber a totalidade da população escolar em idade de frequentar a Educação Pré-escolar e o $1^{\circ} \mathrm{CEB}$ proveniente das freguesias que integram cada um dos territórios. Em termos de $2^{\circ}$ e $3^{\circ}$ CEB e do Ensino Secundário, como referido anteriormente, a opção passou pela manutenção dos estabelecimentos existentes, correspondendo, no caso do $2^{\circ}$ e $3^{\circ} \mathrm{CEB}$, cada um dos estabelecimentos a um território educativo, enquanto no caso do Ensino Secundário a resposta manteve-se em termos municipais. No entanto, deve ser salientado que no que se refere à Educação Pré-escolar a opção passou por manter, numa primeira fase, alguns dos atuais equipamentos em funcionamento, isto numa lógica de proximidade, e que as duas escolas profissionais, que apresentam ofertas diferenciadas, devem funcionar como oferta complementar ao Ensino Secundário.

Como facilmente se observa, a proposta apresentada para o território de Montemor-o-Velho obedeceu a um forte carácter técnico, aquilo que foi considerado como do tipo "decretado" (Cordeiro e Martins, in press), seguindo critérios de planeamento com lógicas bem definidas, quer de otimização dos recursos existentes, mas, acima de tudo, das necessidades previstas razão pela qual a proposta plasmada na Carta Educativa e no Projecto Nacional (NUT's III) apresentou muitas semelhanças.

A proposta de reorganização da rede escolar para o território municipal de Montemor-o-Velho tornaria assim possível orientar o investimento municipal, efetuar um efetivo planeamento e ordenamento do território e, mais importante que tudo isto, preparar o município para os desafios crescentes na área da educação, oferecendo deste modo condições de total igualdade de acesso ao ensino de qualidade aos alunos dos diferentes territórios.

Mas, e se o caso de Montemor-o-Velho o processo de reorganização se apresentou como relativamente simples, o mesmo já não se pode dizer do exemplo do vizinho Município de Coimbra. Por força do seu posicionamento no Centro Litoral, por abranger uma bacia demográfica de cerca de quatrocentos mil habitantes e por apresentar uma tradição bastante antiga em termos educativos, este Município apresenta uma elevada capacidade de atração na totalidade dos níveis de ensino (CMC, 2008). Por esta razão, qualquer estudo relacionado com a reorganização do parque escolar tem obrigatoriamente de equacionar a contínua e histórica mobilidade observada, não só internamente, mas também a verificada em termos intermunicipais.

A todos estes aspetos acresce o elevado número de estabelecimentos de ensino da rede particular com contrato de associação (nove estabelecimentos de $2^{\circ}$ e $3^{\circ} \mathrm{CEB}$ e seis estabelecimentos de Ensino Secundário), que transformam por completo as lógicas habituais de mobilidade escolar, dificultando ainda mais todo o processo. Aliás, a existência deste significativo número de estabelecimentos de ensino da rede particular e cooperativa cria ainda outro problema, que teve de ser analisado em profundidade, uma vez que em determinados sectores do território observam-se baixas taxas de ocupação da rede pública, facto que mostra um claro excedente de salas de aula, e logo de possíveis turmas, em especial no que é considerado como a sua zona urbana.

Desde o início da análise, uma questão dominou todo o processo de reorganização da rede do município. Em termos demográficos, e atendendo aos registos de nascimentos observados em Coimbra, constata-se que em 2013/14 deverão vir a frequentar o $1^{\circ}$ CEB menos 763 crianças, isto quando comparado com os dados de nascimentos registados no período referente ao ano de 2008/09 (os nascimentos passaram de 5651 para 4888 no período referente a 2013/14). Este decréscimo, que tem sido contínuo ao longo das últimas duas décadas, vai apresentar-se em "cascata" relativamente aos outros níveis de ensino até ao final da $2^{\mathrm{a}}$ década deste século XXI.

Simultaneamente, e por força das recentes dinâmicas urbanísticas no município, observa-se uma mobilidade intermunicipal (446 crianças e jovens) e, em particular, intramunicipal (1818 crianças e jovens), realçando-se destes dados as quase cinco centenas de crianças que todos os dias saem da freguesia periurbana de Eiras para frequentar o $1^{\circ} \mathrm{CEB}$ nas escolas do centro urbano.

Por todas estas razões, a proposta de reorganização do parque escolar do Município de Coimbra obedeceu a algumas especificidades (CORDEIRO coord., 2008), começando pela introdução do $1^{\circ} \mathrm{CEB}$ em alguns dos atuais estabelecimentos de $2^{\circ}$ e $3^{\circ}$ CEB (em particular os das zonas rurais e periurbanas), os quais passariam, deste modo, a funcionar como EBI's, e pela passagem de alunos de $3^{\circ}$ CEB para estabelecimentos de Ensino Secundário, já que alguns destes têm vindo a apresentar uma diminuição crescente da taxa de ocupação - os de caraterísticas periurbanas e os rurais -, e tudo istoquando em simultâneo se observaram elevados investimentos no âmbito do programa de requalificação das 
Escolas Secundárias - Parque Escolar - nos estabelecimentos do sector urbano (Figura 5). de $1^{\circ}$ CEB que apresentam maior procura devem sofrer remodelações significativas de modo a criar espaços com

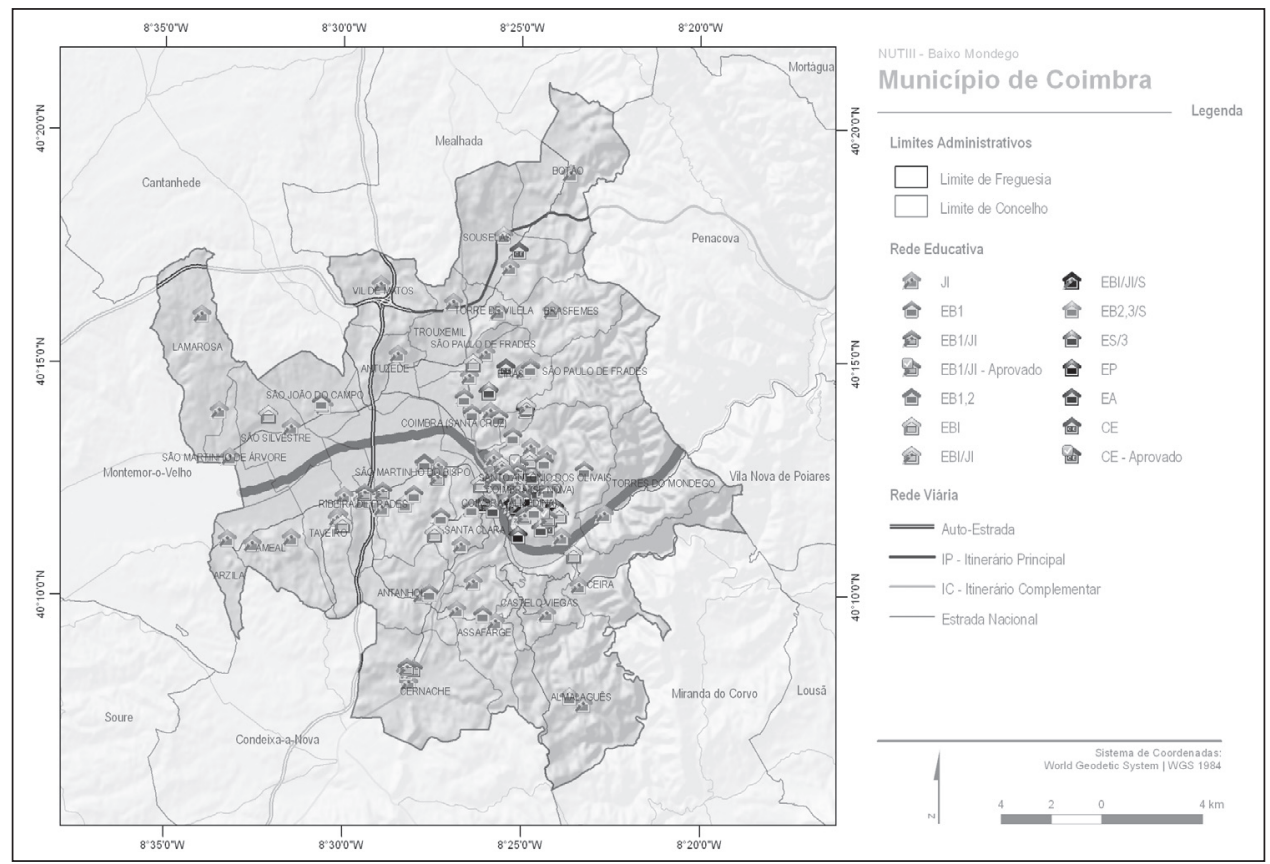

Figura 5

Proposta de reorganização do Município de Coimbra (CoRdeIRo, coord., 2008).

Com base na análise dos nascimentos nos diferentes territórios, bem como da análise dos fluxos, a proposta apresentou, como necessidade premente, a edificação de três Centros Escolares de dimensão "máxima": (i) um no setor da Solum, numa das novas centralidades da cidade e numa das maiores freguesias do município (Santo António dos Olivais, com cerca de 40000 residentes), que deverá funcionar como resposta para o crescimento da população escolar aqui observado, bem como para o solucionar das questões do desdobramento de horários que na altura ainda se observavam neste sector do município; (ii) um em Eiras, que, localizado no vale de Eiras/Santa Apolónia, deverá funcionar como um pólo do sector norte, servindo mesmo de "tampão" aos fluxos observados em direção ao centro urbano (só da Freguesia de Eiras são observados 408 alunos de $1^{\circ}$ CEB a frequentar os estabelecimentos de ensino das freguesias do centro urbano); (iii) um outro Centro Escolar deveria ser edificado na margem esquerda do rio Mondego, mais propriamente na Freguesia de São Martinho (ou em alternativa na de Santa Clara), o qual deveria vir a funcionar na mesma lógica de "tampão" ao movimento centrífugo que os estabelecimentos educativos do centro urbano produzem. No sentido de procurar uma igualdade na qualidade da oferta em termos do edificado escolar, algumas das escolas características semelhantes às dos equacionados Centros Escolares anteriores. São exemplos dessas necessidades as EB1's Vale das Flores, Montes Claros, Almalaguês, Cernache, Souselas, entre outras (CORDEIRO, coord., 2008).

Simultaneamente, e até pelas características do próprio município, a futura rede escolar deveria, de acordo com o proposto no documento de base, apontar para a realidade do século $X X I$, pelo que a totalidade dos estabelecimentos de ensino de $1^{\circ} \mathrm{CEB}$ devem vir a integrar um número mínimo de quatro espaços letivos, de modo a garantir o funcionamento de um ano de escolaridade e um professor por sala de aula, um pouco em sentido oposto ao que tinha sido considerado na carta educativa do município, a qual defendia escolas por vezes com um número de salas inferior a quatro (CMC, 2008) e que, por esta e por algumas outras razões, foi identificada como uma carta de tipo "comunitário" (CORDEIRO e MARTINS, in press) ${ }^{6}$.

${ }^{6} \mathrm{Na}$ proposta de reorganização foram mesmo equacionados encerramentos de escolas da rede pública a médio prazo, que não só as habituais de $1^{\circ} \mathrm{CEB}$. Por forca das características de qualidade dos equipamentos em si - Escola Secundária Jaime Cortesão -, pelo mau planeamento inicial das escolas, EB 2,3 de Ceira e Escola Secundária D. Dinis - ou por alterações que se foram verificando em termos urbanísticos e viários - EB 2,3 Silva Gaio -, foi indicado, na proposta para a Tutela, a possibilidade de encerramento destes estabelecimentos, isto considerando, no essencial, o decréscimo populacional escolar que se prevê para os próximos anos no município. 
À semelhança do Município de Coimbra, o processo de reorganização da rede escolar do Município de Seia caracterizou-se por uma forte complexidade, embora por razões totalmente distintas. Se no caso do território anterior, este se caracterizava por uma grande capacidade de atração, uma forte mobilidade e um elevado número de alunos (embora mostrando uma tendência de diminuição crescente), no caso do município do interior a principal característica demográfica do território passa por uma dinâmica fortemente regressiva, muito ligada às difíceis acessibilidades do território associadas às características morfológicas relacionadas com a Cordilheira Central, nos seus sectores meridional e centro-ocidental.

Em função das características de montanha que parte deste território municipal apresenta, a proposta de reorganização do parque escolar deste município foi efetuada com cuidados acrescidos, não seguindo, por razões óbvias, os pressupostos a que as orientações discutidas com a tutela obrigavam, embora nunca descurando os princípios que the estavam subjacentes: a obtenção de um ensino de qualidade e em condições de igualdade para todos os alunos (CORDEIRO, coord., 2009).

Considerando todos estes aspetos, a proposta passou pela integração da Educação Pré-escolar nos estabelecimentos de ensino afetos ao $1^{\circ} \mathrm{CEB}$, bem como pela manutenção do $2^{\circ}$ e $3^{\circ}$ CEB num só equipamen- to educativo, enquanto os estabelecimentos de Ensino Secundário poderão, pontualmente, integrar o $3^{\circ} \mathrm{CEB}$ (Figura 6). Ainda relativamente à Educação Pré-escolar, optou-se, muito por força das características de montanha de parte do território, pela manutenção de alguns estabelecimentos, mesmo que o número de alunos não o justificasse à partida.

Neste caso particular (aliás, a solução foi idêntica noutros territórios com caraterísticas morfológicas e de acessibilidades semelhantes), e por força da difícil mobilidade observada no sector de montanha - em particular todo o setor de Loriga (vertente ocidental da Serra da Estrela), a proposta passou pela manutenção de um estabelecimento de $1^{\circ}$ CEB com apenas duas salas de aula, já que o número de alunos nos próximos anos não justificava mais do que dois espaços letivos. Esta proposta só em situações muito particulares (zonas de montanha do Norte e do Centro, a serra algarvia ou sectores particulares de territórios municipais como é bom exemplo o caso de Mértola) foi defendida. A justificação para esta exceção passou pelo tempo de duração da viagem das crianças entre o sector de Loriga/ Vale do Alva (Vide) até uma escola que deveria passar a localizar-se em São Romão, mostrando como a proposta refletiu algo que se defendia em termos de acesso ao ensino pelas crianças de sectores de complexidade morfológica elevada.

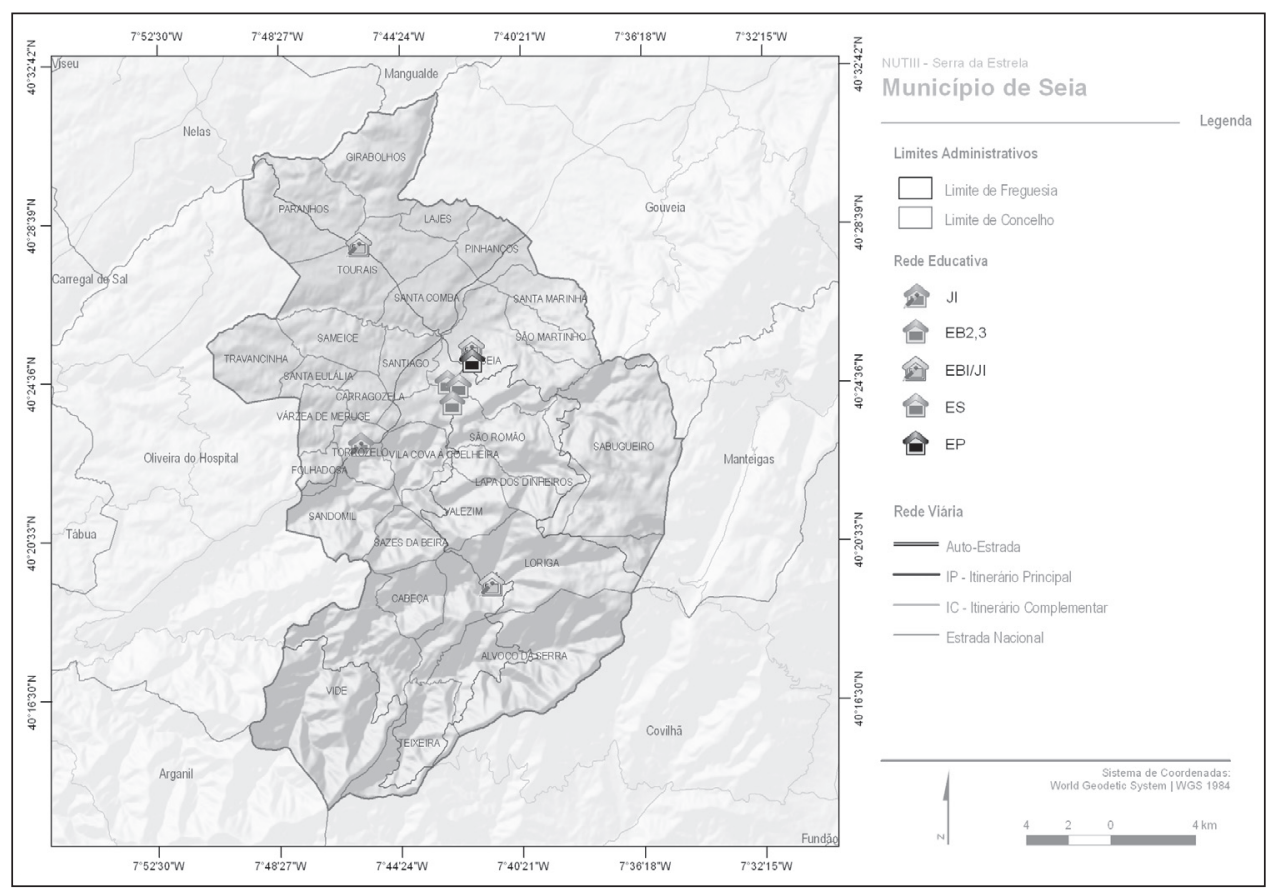

Figura 6

Proposta de reorganização do Município de Seia (Cordeiro, coord., 2009). 
Como facilmente se pode observar pela análise das propostas de reorganização apresentadas para estes três territórios municipais com características tão diferenciadas entre si, as lógicas utilizadas em cada um deles tiveram um fundo comum, embora as soluções não tenham sido as mesmas. Apesar de não se terem descurado os objetivos iniciais a atingir, e que foram definidos inicialmente entre a equipa do Ministério da Educação e a equipa que desenvolveu o projeto, tal foi efetuado de forma a respeitar as especificidades próprias de cada território, mostrando que a proposta, ao ter em linha de conta os fatores geográficos diferenciadores, refletiu uma reorganização que, em situação alguma, se assumiu como demasiado rígida, ou seja de tipo "régua e esquadro".

\section{Alguns aspetos conclusivos}

0 projeto de reorganização da rede educativa equacionado pelo GEPE - "Projeção do Parque Escolar por NUT III a 2013" - pretendeu, desde o seu momento inicial (2008), contribuir para um efetivo planeamento e ordenamento da rede educativa a nível nacional. Porém, em territórios que se apresentam como muito diferenciados em termos das bases de análise, e mesmo que as propostas passassem por uma tentativa de otimização a nível nacional, ele nunca se baseou num "fundamentalismo" da rede escolar que levasse a que a qualidade de vida das crianças e jovens de um qualquer município fosse colocada em causa.

Só com base num projeto com as características do que foi desenhado, com a análise a ser efetuada da escala local para a regional (num momento final, ela deveria mesmo ser equacionada em termos nacionais), se tornaria exequível um efetivo planeamento das intervenções a realizar, sempre com base no princípio da otimização dos recursos, quer existentes, quer previstos, adequando assim a oferta à procura real.

Foi assumido desde o início do processo mais do que um simples diagnóstico da situação atual em termos de distribuição da rede escolar nacional e da objetiva análise comparativa do entretanto equacionado pelas mais de três centenas de Cartas Educativas Municipais. Pretendeu-se, assim, concretizar um conjunto de propostas que, com base num número significativa de variáveis, deveriam apontar para o que se pretende em termos da rede escolar no primeiro quartel do século XXI.

Contudo, pareceu evidente, desde o primeiro momento, ser inquestionável que este projeto deveria ter sido realizado num momento anterior à realização daquelas Cartas Educativas Municipais, oferecendo, assim, uma base de trabalho na concretização desses documentos de índole local, mas perspetivando-se e potenciando-se, desde logo, algumas análises de carácter intermunicipal.

Todas as análises e organizações da rede educativa anteriores desenvolveram-se ainda num quadro do que era considerado como um planeamento tradicional, não visando lógicas do que é, no presente, pretendido em termos de planeamento estratégico. Neste sentido, a ambição colocada desde o primeiro momento do projeto só seria possível de atingir através da análise de inúmeros fatores relacionados com o sistema educativo, pois só com base num retrato fiel da dinâmica escolar se tornaria possível efetuar um efetivo planeamento da rede educativa.

As condicionantes naturais que caracterizam muitos setores do território nacional, em particular os sectores de montanha ou as áreas onde os cursos de água podem funcionar como barreiras à mobilidade, assim como de contextos demográficos e socioeconómicos que se apresentam em sectores de baixa densidade, foram fatores decisivos na análise realizada. De igual modo o decréscimo populacional escolar que é a imagem mais comum destes setores, ao contrário do que se observa no litoral, onde o crescimento em muitos casos chegou a duplicar a população residente na $2^{\mathrm{a}}$ metade do Século XX (momento em que foi definida a rede escolar do "Plano Centenário"), tornaram globalmente este processo de reorganização do parque escolar nacional um projeto de extrema complexidade, mas cuja observação particular, sem análises e propostas efetuadas de modo rígido, foi determinante para que se atingissem grande parte dos objetivos propostos.

Com esta proposta, que à partida deveria vir a ter interferência efetiva na rede educativa nacional, verificou-se em muitas situações a necessidade de uma significativa redução do número de estabelecimentos de ensino, no sentido de a adequar à realidade demográfica dos nossos dias, enquanto noutros territórios se observou uma necessidade efetiva de edificação de novos espaços educativos. De igual modo, constatou-se que em muitos territórios a reorganização deveria passar por uma lógica intermunicipal, situação muito raramente equacionada "Cartas Educativas Municipais", diferentes onde as lógicas locais predominaram relativamente às subregionais.

Naturalmente, todas as propostas de reorganização do parque escolar apresentadas tiveram em linha de conta a adaptação ao comportamento da população escolar e aos aspetos de natureza física e demográfica que caracterizam cada território, tendo igualmente em consideração a observação das dinâmicas e fluxos exis- 
tentes entre diferentes espaços, analisando o território sempre como um todo.

O processo considerou ainda o facto da diminuição do número de estabelecimentos de ensino conduzir, por um lado, a um aumento da qualidade da oferta, uma vez que estes passam a estar adaptados às novas exigências pedagógicas, administrativas e sociais que têm vindo a ser apresentadas, e a uma melhor gestão dos meios disponíveis e, por outro lado, ao repensar da rede de transportes escolares, de modo a que a reorganização da rede educativa nacional saída deste projeto se traduza efetivamente num aumento da qualidade de vida da população escolar.

A análise comparativa entre as "Cartas Educativas Municipais" e os relatórios até ao momento efetuados do projeto "Projeção do Parque Escolar por NUT III a 2013", torna evidente que a grande diversidade de soluções encontradas pelos Municípios na reorganização da rede escolar só em parte refletiram as orientações apresentadas pela Tutela, e que só raramente refletiram um efetivo planeamento estratégico. Aliás, parece ser evidente que muitos dos equipamentos edificados com base nas propostas formuladas nas "Cartas Educativas Municipais" se encontram sobredimensionados, razão pela qual se vão observar, e já num futuro próximo, situações em que a lotação na altura equacionada, se vai apresentar muito superior ao número de nascimentos observados nos diferentes territórios nacionais.

\section{Bibliografia}

Afonso, A. (1997) - "Para a configuração do Estado-providência na educação em Portugal, 1985-1995”. Educação, Sociedade e Culturas, n. $^{\circ}$ 7, Lisboa.

Alcoforado, J. L. M.; Cordeiro, A. M. Rochette e Ferreira, S. M. (in press) - "A (re)organização da rede escolar como reflexo das transformações demográficas, políticas e geográficas, nas últimas seis décadas em Portugal”. Atas do IX Congresso Luso-Brasileiro da História da Educação, Universidade de Lisboa, Lisboa.

Barreto, António (2000) - "Portugal e a Europa: quatro décadas". A situação social em Portugal: 1096-1999, Instituto de Ciências Sociais da Universidade de Lisboa, Lisboa.

Cabral, J. e Marques, T. (1996) - "Do planeamento estratégico ao desenvolvimento sustentável: experiência em Portugal". Inforgeo, n. ${ }^{\circ} 11$, Lisboa.

Câmara Municipal de Coimbra (2008) - Carta Educativa de Coimbra 2008-2015. Faculdade de Ciências e Tecnologia da Universidade de Coimbra, Coimbra.
Câmara Municipal de Montemor-o-Velho (2006) - Carta Educativa do Município de Montemor-o-Velho. Faculdade de Letras da Universidade de Coimbra, Coimbra.

Câmara Municipal de Sela (2007) - Carta Educativa do Concelho de Seia. Divisão de Cultura, Educação e Desporto, Seia.

Cordeiro, A. M. Rochette (coord) (2008) - "Sub-região do Baixo Mondego". Projeção do Parque Escolar por NUT III a 2013, Faculdade de Letras da Universidade de Coimbra, Coimbra.

CoRdeiro, A. M. Rochette (coord) (2009) - "Sub-região da Serra da Estrela". Projeção do Parque Escolar por NUT III a 2013, Faculdade de Letras da Universidade de Coimbra, Coimbra.

CoRdeIRo, A. M. Rochette (2011) - "Reorganização da Rede Escolar”. Boletim dos Professores, $n^{\circ} 20$, Ministério da Educação, Lisboa.

Cordeiro, A. M. Rochette e Martins, H. A. (in press) - "A Carta Educativa Municipal como instrumento estratégico de reorganização da rede educativa: tendências de mudança”. Cadernos de Geografia, n. ${ }^{\circ} 30-31$, Instituto de Estudos Geográficos, Coimbra.

DGOTU (1996) - Normas para a programação e caracterização de equipamentos coletivos. DGOTU, Lisboa.

FAzendeIro, A. (1992) - Carta Escolar da Região Alentejo. Gabinete de Estudos e Planeamento - Ministério da Educação, n. ${ }^{\circ}$ 11-22, Lisboa.

Gabinete de Estudos e Planeamento (1992a) - Carta escolar da Região Centro. Gabinete de Estudos e Planeamento - Ministério da Educação, Lisboa.

Gabinete de Estudos e Planeamento (1992b) - Carta escolar da Região Alentejo. Gabinete de Estudos e Planeamento Ministério da Educação, Lisboa.

Martins, H. A.; Neto-Mendes, A. A. e Cordeiro, A. M. Rochette (2011) - "Cartas Educativas: um olhar sobre soluções de reordenamento da rede escolar e mudanças no(s) território(s)," II Encontro de Sociologia da Educação "Educação, Territórios e Desigualdades, Faculdade de Letras da Universidade do Porto, Porto.

RodRIGUES, M. L. (2010) - A Escola pública por fazer a diferença, Almedina, Coimbra.

Santos, B. S. (1994) - Pela Mão de Alice: o Social e o Político na Pós-Modernidade. Edições Afrontamento, Porto.

Vasconcelos e Sá, M. (1990) -A Intervenção Sociológica no Planeamento. Universidade Técnica de Lisboa, Lisboa.

Lei n. ${ }^{\circ}$ 46/86 de 14 de Outubro, Diário da República, n. ${ }^{\circ} 237$, I Série, Assembleia da República, Lisboa.

Decreto-Lei n. ${ }^{\circ}$ 7/2003 de 15 de Janeiro, Diário da República, n. ${ }^{\circ} 12$, I Série - A, Ministério das Cidades, Ordenamento do Território e Ambiente, Lisboa. 